www.jmscr.igmpublication.org Impact Factor 5.244

Index Copernicus Value: 83.27 ISSN (e)-2347-176x ISSN (p) 2455-0450 crossref DOI:_http://dx.doi.org/10.18535/jmscr/v4i7.07

Journal Of Medical Science And Clinical Research

\title{
Histopathological Patterns of Ovarian Tumours: A Hospital Based Study (Research Paper)
}

\author{
Author
}

\section{Dr Dharmakanta Kumbhakar}

Associate Professor, Pathology Department, Tezpur Medical College and Hospital, Tezpur, Assam

Corresponding Author

Dr Dharmakanta Kumbhakar

Associate Professor, Department of Pathology, Tezpur Medical College and Hospital, Tezpur, Assam

Email:drkdharmakanta@yahoo.com

\section{ABSTRACT}

Background: - Ovary is the site for more than two dozen different tumours with its varied histopathological patterns. Relative frequency of these histopathological patterns is different for Western and Asian countries. Ovarian cancer is one of the most frequent causes of death from gynaecological malignancies.

Aims and Objectives: - A hospital based study to determine the histopathological patterns of ovarian tumours. Material and Methods: - The present study is based on the histopathological analysis of 70 specimens of clinically and radiologically diagnosed ovarian tumours presented at Patholgy department of Tezpur Medical College and Hospital, Tezpur, Assam for histopatholcical examination in the period of two years from June 1, 2014 to May 31, 2016.

Result and observations: - Out of 70 ovarian tumours, $46(65.71 \%)$ were benign tumour, $2(2.86 \%)$ were borderline and $22(31.43 \%)$ were malignant tumour. Among benign tumours, benign cystic teratoma (30.00\%) was the commonest followed by serous cystadenoma (22.86\%) and mucinous cystadenoma (8.57\%). Among the malignant tumours, the most common type was serous cystadenocarcinoma. Surface epithelial tumour (57.14\%) was the commonest tumour according to the histogenesis followed by germ cell tumour (34.29\%), sex cord tumours $(7.14 \%)$ and metastatic tumour (1.43\%). The mean age of the subjects was 35.2 years, ranging from 8 to 70 years. Abdominal mass was the most predominant clinical presentation.

Conclusion:- Ovarian tumours need histopathological examination for proper diagnosis and follow up of patients. This study gives the histopathological pattern of ovarian tumours of the cases that attended our institute with different clinical presentations. As it is a hospital based study, it might not reflect the exact scenario of the population at large.

Key Words: Surface epithelial tumour, Dermoid cyst, Cystadenocarcinoma Dysgerminoma, Sex cord stromal tumour, kruckenberg tumour.

\section{Introduction}

Ovary is the site for more than two dozens different tumours with its varied histopathological patterns. The normal ovary is composed of three cell types- the multipotential surface (coelomic) covering epithelium, the totipotential germ cells and the multipotential sex cord/ stromal cells. Each of these cell types gives rise to a variety of ovarian tumours ${ }^{(1)}$. They are rare in young age 
group and commonly present with abdominal pain, an abdominal lump or menstrual irregularities. Each of these tumours morphologically can present as cystic, adenofibromatous or solid tumour. Depending on the tumour cell morphology, proliferative pattern and other associated findings (haemorrhage, necrosis, calcification \& others), it may be graded as benign, borderline and malignant tumours ${ }^{(2)}$. Tumours of surface epithelial origin account for the great majority of primary ovarian tumours, and in their malignant forms account for almost $90 \%$ of ovarian cancers. Germ-cell and sex cord /stromal cell tumours are much less frequent and, although they constitute $20 \%$ to $30 \%$ of ovarian tumours, are collectively responsible for fewer than $10 \%$ of malignant tumours of the ovary ${ }^{(2)}$.

Ovary is an important site of cancer in women. Indian cancer Registry data project that ovarian cancer comprises upto $8.7 \%$ of cancers in different parts of India ${ }^{(3)}$. In Assam, relative proportion of ovarian cancer is almost $4.9 \%$. It is one of the most frequent causes of death from gynaecological malignancies ${ }^{(4,5)}$.

\section{Aims and Objectives}

The present study is carried out with an aim to evaluate the histopathological patterns of the ovarian tumours.

\section{Material and Methods}

The study was carried out on 70 specimens of clinically and radiologically diagnosed ovarian tumours received in the Department of Pathology, Tezpur Medical College and Hospital, Tezpur, Assam for histopatholcical examination in the period of two years from June 1, 2014 to May 31, 2016. Data regarding their clinical profile was collected from the gynaecology department of the institute.

A total of 70 specimens of ovarian tumours underwent biopsy interpretation. The Nature of specimens was either in the form of simple oopherectomy or hysterectomy with unilateral /bilateral salpingo-oopherectomy. The specimens collected for the study was sent by the gynaecology department of the institute fixed in $10 \%$ formalin. The specimens were observed grossly in the Pathology department as per guideline described by standard text book of surgical pathology ${ }^{(1)}$ and findings were noted in the note sheet. Omentum was looked for any nodularity. Lymph nodes were also dissected out along with biopsy tissue. The biopsy tissue were then sectioned and processed in the conventional manner as described by J D Bancroft and Marilyn Gamble ${ }^{(6)}$. After completion of processing, they were made in paraffin blocks and cut in rotatory microtome of about 3- $5 \mu$ thickness. The sections were stained by conventional Haematoxylin and Eosin, mounted in DPX and examined under microscope. The microscopic slides were viewed under low power field and high power field. The findings were noted and interpreted according to WHO classification.

\section{Result and observation}

The study included a total of 70 specimens of clinically and radiologically diagnosed ovarian tumours for histopathological evaluation. The age of the patients ranged from 8 to 70 years with a mean age of 35.2 years. Majority of the patients were in the age groups 31-40 years (Cite Table1). Bilateralism was detected in $10.00 \%$ of the total cases.

Table 1: Age Distribution of Patients with ovarian tumours $(\mathrm{N}=70)$.

\begin{tabular}{|l|l|l|}
\hline Age (Years) & No. of Cases & Percentage \\
\hline $1-10$ & 1 & $1.43 \%$ \\
\hline $11-20$ & 6 & $8.57 \%$ \\
\hline $21-30$ & 15 & $21.43 \%$ \\
\hline $31-40$ & 22 & $31.43 \%$ \\
\hline $41-50$ & 18 & $25.71 \%$ \\
\hline $51-60$ & 6 & $8.57 \%$ \\
\hline $61-70$ & 2 & $2.86 \%$ \\
\hline
\end{tabular}

Out of the 70 ovarian tumours, 37 cases $(52.86 \%)$ were cystic, 24 cases $(34.28 \%)$ were solid/cystic and 9 cases $(12.86 \%)$ were predominantly solid tumours (Cite Table-2). 
Table 2: Consistency of the Ovarian Tumour $(\mathrm{N}=70)$

\begin{tabular}{|l|l|l|}
\hline Consistency & $\begin{array}{l}\text { No. of } \\
\text { cases }\end{array}$ & Percentage \\
\hline Cystic & 37 & $52.86 \%$ \\
\hline Cystic/Solid & 24 & $34.28 \%$ \\
\hline Solid & 09 & $12.86 \%$ \\
\hline
\end{tabular}

Out of the 70 ovarian tumours, 46 cases $(65.71 \%)$ were benign tumour, 2 cases $(2.86 \%)$ were borderline and $22(31.43 \%)$ cases were malignant tumour (Cite Figure 1).

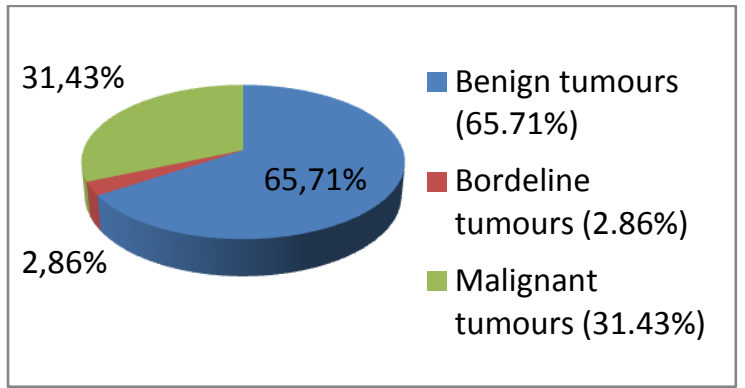

Figure-1- Frequency of benign and malignant ovarian tumours

Most of the benign ovarian tumours presented as cystic masses. Surface epithelial tumour (40 cases- $57.14 \%$ ) was the commonest tumour according to the histogenesis followed by germ cell tumours (24 cases- $34.29 \%$ ), sex cord tumours (5 cases-7.14\%) and metastatic tumours (1 cases$1.43 \%)$.

In the surface epithelial benign tumour category, serous cystadenoma constituted highest numbers $(22.86 \%)$ followed by mucinous cystadenoma $(8.57 \%)$. The borderline tumours were mucinous type. Among the malignant surface epithelial tumours, the incidence of mucinous cystadenocarcinoma was $8.57 \%$, papillary cystadenocarcinoma was $7.14 \%$, serous cystadenocarcinoma was $4.28 \%$, endometrioid adenocarcinoma was $1.43 \%$ and clear cell carcinoma was $1.43 \%$. In the germ cell tumour category, benign cystic teratoma constituted highest numbers $(30.00 \%)$, followed by dysgerminoma $(1.43 \%)$, yolk sac tumour $(1.43 \%)$ and choriocarcinoma was $1.43 \%$. Germ cell tumour was found in age group- 1 to 40 years. Out of 5 cases of sex cord stromal tumour, $4.28 \%$ was benign tumour as fibroma, $1.43 \%$ granulose cell tumour and $1.43 \%$ Sertoli Leydig cell tumour. One case (1.43\%) of metastatic tumour (kruckenberg tumour) was also detected in the study (Cite Table 3).

Table 3: Showing break-up of different ovarian tumours (Total- 70)

\begin{tabular}{|c|c|c|}
\hline Tumours & Number & Percentage \\
\hline (A)Surface $\quad$ Epithelial & 40 & $57.14 \%$ \\
\hline tumours & & \\
\hline (1) Benign- & 22 & $31.43 \%$ \\
\hline (i) Serous cyst adenoma & 16 & $22.86 \%$ \\
\hline $\begin{array}{l}\text { (iii)Mucinous } \quad \text { cyst } \\
\text { adenoma }\end{array}$ & 6 & $8.57 \%$ \\
\hline (2) Borderline & 2 & $2.86 \%$ \\
\hline (i) Mucinous borderline & 2 & $2.86 \%$ \\
\hline (3) Malignant- & 16 & $22.85 \%$ \\
\hline (i)Mucinous & 6 & $8.57 \%$ \\
\hline cystadenocarcinoma & & \\
\hline $\begin{array}{l}\text { (ii)Papillary serous } \\
\text { cystadenocarcinoma }\end{array}$ & 5 & $7.14 \%$ \\
\hline (ii)Serous & 3 & $4.28 \%$ \\
\hline $\begin{array}{l}\text { cystadenocarcinoma } \\
\text { (iii)Endometrioid }\end{array}$ & 1 & $143 \%$ \\
\hline carcinoma & & \\
\hline (iv) Clear cell carcinoma & 1 & $1.43 \%$ \\
\hline (B) Germ Cell tumours & 24 & $34.29 \%$ \\
\hline (i) Benign cystic teratoma & 21 & $30.00 \%$ \\
\hline (ii) Choriocarcinoma & 1 & $1.43 \%$ \\
\hline (iii) Dysgerminoma & 1 & $1.43 \%$ \\
\hline (iv) Yolk sac tumour & 1 & $1.43 \%$ \\
\hline $\begin{array}{l}\text { (C) Sex cord stromal } \\
\text { tumours }\end{array}$ & 5 & $7.14 \%$ \\
\hline (i) Fibroma & 3 & $4.28 \%$ \\
\hline (ii) Granulosa cell tumour & 1 & $1.43 \%$ \\
\hline $\begin{array}{l}\text { (iii) Sertoli Leydig cell } \\
\text { tumour }\end{array}$ & 1 & $1.43 \%$ \\
\hline (D) Metastatic tumour & 1 & $1.43 \%$ \\
\hline (Kruckenberg tumour) & 1 & $1.43 \%$ \\
\hline
\end{tabular}

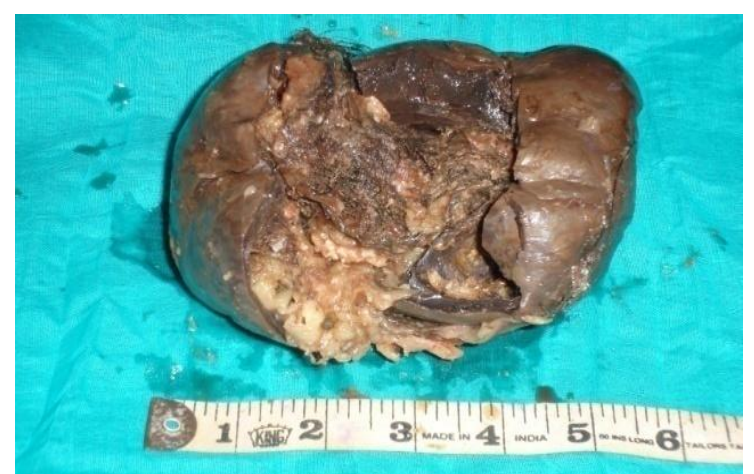

Fig 2- Gross picture of benign cystic teratoma. 


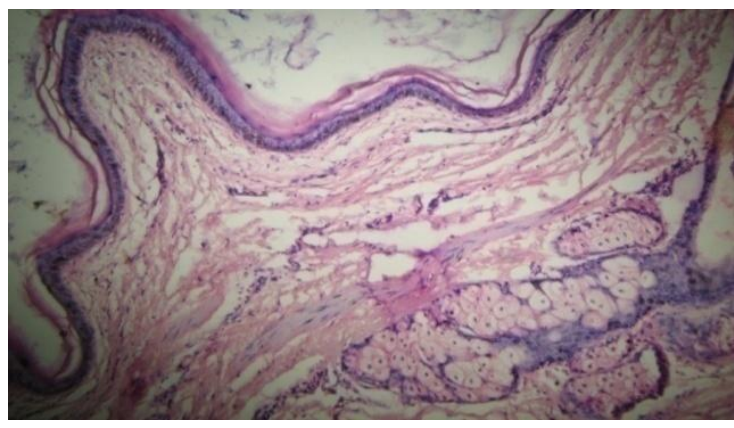

Fig 3- Microscopy of benign cystic teratoma, H\& E (High power view)

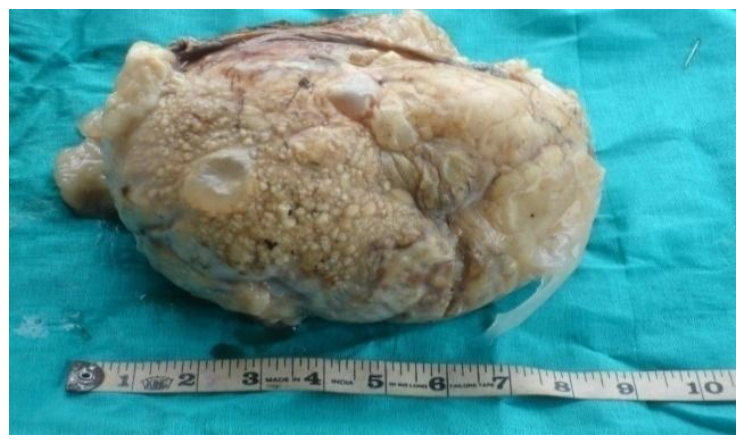

Fig 4- Gross picture of mucinous cystadenocarcinoma.

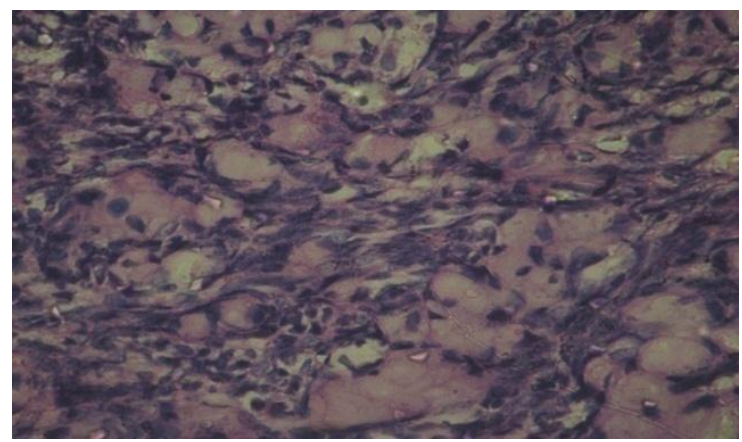

Fig 5- Microscopy of Kruckenberg tumour, H\& E (High power view)

\section{Discussion}

Ovarian tumours may occur at any age. In our study the age of the patients ranged from 8 to 70 years with a mean age of 35.2 years, majority of the patients were in the age groups 31-40 years, which is concordance with Couto $\mathrm{F}$ et al $2006^{(7)}$. Bilateralism was detected in $10.00 \%$ of the total cases in our study, which most comparable with the study of Madan et al 1978 and Verma et al $1981(8,9)$, reported a low incidence of $11 \%$ and $11.91 \%$ bilaterism.

In our study most of the benign tumour was cystic as comparable to malignant, which was solid in consistency followed by partly cystic and partly solid. We found $52.86 \%$ cystic, $12.86 \%$ solid and $34.28 \%$ semisolid or partly cystic. The result is concordancewith Gupta et al 2007, Madan et al 1978, Prabhakar et al 1989, and Mishra et al 1992. $(3,8,10,11)$

The ovarian tumour is diagnosed as benign, borderline and malignant depending on the presence of predominant cell type, pattern of growth, amount of fibrous stroma and cellular atypia with invasiveness ${ }^{(2)}$. In our study we found $65.71 \%$ benign, $2.86 \%$ borderline and $31.43 \%$ malignant. Similar observations were found in other studies also (cite table 4).

Based on histo-morphological features, incidence of surface epithelial tumours were commonest surface epithelial tumour $(57.14 \%)$ followed by germ cell tumour (34.29\%), sex cord tumours (7.14\%) and metastatic tumours (1.43\%). Similar observations were seen in other studies (cite table$5)$.

Table 4- Comparision of frequency of ovarian tumours with other study

\begin{tabular}{|l|l|l|l|}
\hline Studies & Benign & $\begin{array}{l}\text { Borde } \\
\text {-rline }\end{array}$ & $\begin{array}{l}\text { Malig- } \\
\text { nant }\end{array}$ \\
\hline $\begin{array}{l}\text { Gupta et } \\
\text { al.2007 }\end{array}$ & $72.9 \%$ & $4.1 \%$ & $22.9 \%$ \\
\hline $\begin{array}{l}\text { Pilli et al } \\
2007\end{array}$ & $75.2 \%$ & $2.8 \%$ & $21.8 \%$ \\
\hline $\begin{array}{l}\text { Mandal SK et } \\
\text { al.2011 }\end{array}$ & $63.1 \%$ & $7.3 \%$ & $29.6 \%$ \\
\hline Our study & $65.71 \%$ & $2.86 \%$ & $31.43 \%$ \\
\hline
\end{tabular}

Table 5- Comparative incidence of ovarian tumours according histogenesis

\begin{tabular}{|l|l|l|l|l|}
\hline Studies & $\begin{array}{l}\text { Surface } \\
\text { epithelial }\end{array}$ & $\begin{array}{l}\text { Germ } \\
\text { cell }\end{array}$ & $\begin{array}{l}\text { Sex } \\
\text { cord } \\
\text { /stroma }\end{array}$ & $\begin{array}{l}\text { Metas- } \\
\text { tatic }\end{array}$ \\
\hline $\begin{array}{l}\text { Pilli et al } \\
2007\end{array}$ & $70.9 \%$ & $21.2 \%$ & $6.7 \%$ & $0.7 \%$ \\
\hline $\begin{array}{l}\text { Gupta et } \\
\text { al.2007 }\end{array}$ & $65.6 \%$ & $23.9 \%$ & $8.3 \%$ & $2.0 \%$ \\
\hline $\begin{array}{l}\text { Bhuvanesh } \\
\text { et al 1978 }\end{array}$ & $78.56 \%$ & $10.85 \%$ & $7.14 \%$ & $1.42 \%$ \\
\hline $\begin{array}{l}\text { Couto F et } \\
\text { al 1993 }\end{array}$ & $68.81 \%$ & $20.39 \%$ & - & $1.46 \%$ \\
\hline Our study & $57.14 \%$ & $34.29 \%$ & $7.14 \%$ & $1.43 \%$ \\
\hline
\end{tabular}


The proportion of benign cystic teratoma was the commonest benign tumour in our study. Sex cordstromal tumours, which comprise approximately $5 \%$ of all ovarian neoplasms, are tumours that differentiate in the direction of sex cords and/or the specialized ovarian stroma, which is consistent with our finding on sex cord stromal tumour. One cases of Kruckenberg tumours were also detected in which primary tumour was in stomach.

\section{Conclusion}

The main strength of this study is that it gives the most comprehensive picture of the current state of ovarian tumours' incidence and histopathological pattern. Surface epithelial tumours are the commonest followed by germ cell tumours. The major limitations of this study include the small sample size and short study period. However A tentative conclusion can be drawn from the present study that ovarian tumours comprise one of the major neoplasms in female detected in this institution.

\section{Acknowledgement}

The author acknowledge the help and co operation received from the faculties of O\&G and Pathology Deptt, Tezpur Medical College and Hospital, Tezpur, Assam while conducting the present study.

\section{References}

1. Juan Rosai (2004), Rosai \& Ackermann's Surgical Pathology, 9th Edition.

2. Cotran, Kumar, Collins (2006), "The female genital tract" Robins Pathologic Basis of Disease.

3. Gupta N, Bisht D, Agarwal AK, Sharma VK. Retrospective and prospective study of ovarian tumours and tumour-like lesions. Indian J Pathol Microbiol 2007; 50:525-7

4. Mondal SK, Banyopadhyay R, Nag DR, Roychowdhury S, Mondal PK, Sinha SK. Histological pattern, Bilaterality and clinical evaluation of 957 ovarian neoplasms: A 10-year study in a tertiary hospital of eastern India. J Can Res Ther 2011; 7:433-7

5. Murthy NS, Shalini S, Suman G, Pruthvish $S$, Mathew A. Changing trends in incidence of ovarian cancer - the Indian scenario. Asian Pac J Cancer Prev 2009; 10:1025-30.

6. John D. Bancroft and Marilyn Gamble. Theory and Practice of Histological Techniques Couto F, Nadkarni NS, Jose $\mathrm{M}$. Ovarian tumours in Goa. A Clinicopathological study. J Obstet Gynecol India 1993, 40 (20 408-11.

7. Couto F, Nadkarni NS, Jose M . Ovarian tumours in Goa. A Clinicopathological study. J Obstet Gynecol India 1993, 40 (20 408-11.

8. Madan A, Tyagi SP, Mohsin S. Incidence of ovarian tumours in Aligarh with particular reference to histopathological typing. J Obsel Gynocol India, 1978; 82732.

9. Verma K, Bhatia A, Ovarian neoplasm-A study of 403 tumours. J Obstel Gynocol India 1981, 406-

10. Prabarker, Maingi K. ovarian tumors prevalence in Punjab. Indian $\mathrm{J}$ Pathol Microbiol 1989; 32: 276-81.

11. Mishra RK, Sharma SP, Gupta U, Gaur R, Mishra SD, Pattern of ovarin neoplasm in eastern UP. J Obstel Gynol, India 1992: 30:2420-46.

12. Pilli G, Sunita kp, Dhaded AV, Ovarian tumours, A study of 282 cases. JIMA. 2002; 100 (7): 1-6.

13. Bhuvanesh U and Logambal A, A study of ovarian tumours. J Osel Gyneacol INDIA 1978:28: 271-77 